\title{
DRIVERS OF WORK ALIENATION: A NARRATIVE REVIEW
}

\author{
Tahira Yawer Ali ${ }^{1}$ \\ Hamdard Institute of Management Sciences, Hamdard University \\ Karachi. \\ Shahid Rasheed ${ }^{2}$ \\ Assistant Professor, Hamdard University \\ Karachi. \\ Dr. Riaz Hussain ${ }^{3}$ \\ Associate Professor, Department of Business Administration \\ Sindh Madressatul Islam University \\ Karachi
}

\begin{abstract}
Purpose:- Work Alienation over the years has been regarded as an important construct in all disciplines but more recently it has been declared as an understudied construct in the domain of Management. In an attempt to contribute some work to re-vitalize this concept, this review paper aims to organize, evaluate and synthesize the fragmented work done on the statistically proven antecedents of work alienation.

Research Methodology:- In order to identify what drives work alienation, a rigorous and extensive study of the literature was conducted through analyzing relevant ISI indexed journals. The published empirical research on work alienation is the main focal point of this narrative review. At the initial stage, the focus was on ISI indexed management journals. The initial analysis helped to identify key antecedents, so the research was made more rigorous through searching related articles in specialized journals as well. Findings:- A summary table is prepared that highlights the extent to which work is done on statistically proven antecedents. The table highlights that much replica is found with little or no modifications in the already developed models

Practical Implications:- The review paper attempts to organize ,evaluate and synthesize the quality literature work done on the topic under review. It opens new avenues for future researchers by highlighting how this construct can be worked upon to contribute and add to the existing body of literature.
\end{abstract}

Keywords : Work alienation, Antecedents, Narrative review

\section{Jel Classification: D63,D60, G38}

\footnotetext{
* The material presented by the author does not necessarily portray the viewpoint of the editors and the management of the Institute of Business \& Technology (IBT)

1. Tahira Yawer Ali : tyawer@yahoo.com

2. Shahid Rasheed

3. Dr. Riaz Hussain

C IBTJBS is published by the Institute of Business and Technology (IBT). Main Ibrahim Hydri Road, Korangi Creek, Karachi-75190, Pakistan.
} 


\section{INTRODUCTION}

In today's era, external factors such as globalization, technological developments and intense rivalry among competitors have forced the organizations to operate and manage in a rapidly developing environment. In such a challenging environment where constant adjustments to outside environment are fundamental ingredient for survival of the organization, it is also observed that there are some negations in behaviors and attitudes of individuals working in the organization towards the organization (Aslan \& Eren, 2014). For years, employee attitude and their feelings towards their employing organization has been an area of interest for many scholars and researchers. The main reason for interest is the reflective impact of employee's attitude on major organizational outcomes. As much as previous researches focus on attitudes that are potentially beneficial for the organizations; the focus on attitudes that can be potentially destructive for the organizations are given equal importance in literature.

One of such negative attitude and state includes isolating oneself from work and work related activities. This state is often referred as work alienation (Ceylan \& Sulu, 2010; Brandes, 1997; Cheung, 2008). Such an attitude can adversely affect not only task performance (Shantz, Alfes, Bailey \& Soane, 2015; Banai \& Reisel, 2003; Chisholm \& Cummings, 1979) and citizenship behaviors (Shantz, Alfes, Bailey \& Soane, 2015; Jesús Suárez-Mendoza \& Zoghbi-Manrique-de-Lara, 2008; Suarez-Mendoza \& ZoghbiManrique- de-Lara, 2007), but can also cause health problems (Armstrong-Stassen, 2006). Kanungo (1983) highlighted that with the objective of enhancing the quality of working life outside and within the organization, Work alienation has become a major area of interest while investigating the psychological and sociological standpoint of organizational effectiveness. Keeping in view the devastating consequences of work alienation, Shantz, Alfes, Bailey \& Soane (2015) highlighted a need to determine other drivers of work alienation apart from decision making autonomy, task variety, task identity and social support.

Although, it is seen that a considerable amount of work has been done to identify what drives work alienation, but to our dismay, the work is fragmented and spread over many years. Our aim is to present in a narrative review, the extent of quality work done on the statistically proven antecedents of work alienation and assemble them into a lens through which scholars could have a better idea of the extent of work done on what causes work alienation. Only then, can the call from Shantz, Alfes, Bailey \& Soane (2015) be better answered and new knowledge in literature can be contributed by examining the left out variables not covered in literature as yet. Moreover, we have presented tabular summaries of the studies organized by the year of their publication in order to compliment this narrative review.

To accomplish our aim, we have organized this article into three sections. The first provides a brief overview on the concept of work alienation. The second portion highlights what is available in literature regarding the antecedents of work alienation and finally, the last portion will provide future avenues. 


\section{OVERVIEW OF WORK ALIENATION}

Alienation is a concept that despite of having rich history, has unfortunately endured relative disregard in organizational studies (Nair \& Vohra; 2012). The term "alienation" is used to define an individual's act to separate itself not only from its own entity, but also from product, natural and social environment and enter their domination (Tolan, 1981). The individual thus becomes gradually helpless and isolated as a result of decreased adaption and control over natural, cultural and social environment (Çetin et al., 2009). However, the term Work Alienation is associated with the working conditions that isolate employees from work and work activities (Sulu, Ceylan \& Kaynak, 2010; Brandes, 1997; Cheung, 2008). This term reflects a position where the employee seems to care less about its work, utilize little energy and is desirous to work only for extrinsic rewards (Michaels, et al., 1988).

The conceptualization of alienation can be traced back to the theory of Marx (1844). Marx identified that under capitalistic society, the creation of new products having economic value is possible by the efforts of workers who invests their labor with natural resources. In this process, the worker's labor is detached from him/ her as the worker's contributed labor becomes objectified and its value is converted into a product that can be purchased and sold in market. Rather than taking the work as something to provide them with sell-fulfillment, they start taking work as a means of survival. Thus, workers feel alienated from the objects/products that they produce themselves.

Seeman (1959) has viewed this construct as having multidimensional nature and declared powerlessness, social isolation, meaninglessness, normlessness and self-estrangement to be the dimensions of alienation. However, there are other group of researchers (such as Mottaz, 1981; Kanungo, 1982, Hirschfeld, Field, Bedeian, 2000) who criticized the treatment of alienation as multi-dimensional construct. They declared alienation to be uni-dimensional. Thus, self-estrangement (separation from work) is considered to be the heart of alienation (Mottaz, 1981; Nair \& Vohra, 2009).

\subsection{What Drives Work Alienation?}

In this section, we attempt to present a narrative review of literature on work alienation with respect to its antecedents i.e. what factors lead to work alienation. The published empirical research on work alienation is the main focal point of this narrative review. At the initial stage, we focused on ISI indexed management journals (e.g. Journal of International Management, Journal of Management Inquiry, The International Journal of Human Resource Management, British journal of management, Journal of Applied Social Psychology). The initial analysis helped us to identify key antecedents, so we made our research more rigorous and extensively searched for related articles in specialized journals as well (e.g. Journal of Business Ethics, Employee Responsibilities and Rights Journal, International Journal of Mental Health Addiction). Although abundance contribution was found in literature related to work alienation, but very few could be selected for this narrative review as our scope was related to identifying only the statistically proven drivers of work alienation.

The table 1 in appendix contains the list of journals from which we reviewed the papers. (See Table 1) 
When these journals were thoroughly analyzed for the literature on drivers of work alienation, we reveal that much replica can be found in literature when it comes to identifying the drivers of alienation. A summary of articles selected for review is presented in Table II (in appendix) where it can be analyzed that many authors has repeatedly worked on same antecedents with little or no modification in their developed models. However, we should elucidate at this point that only the relevant piece of work, suitable to scope of our study has been extracted from these papers. By this we mean that for example; Banai, Reisel, and Probstc (2004) analyzed the impact of leadership, job characteristics, and individual locus of control not only on work alienation but also on organizational commitment, but in our table, we excluded organization communication as a consequence because it is out of the scope for this review paper.

Similarly, a large piece of literature on work alienation highlights the consequences of work alienation such as Hirschfeld, Field, Bedeian (2000) identified that work alienation is the predictor of job involvement, affective organizational commitment, affective occupational commitment, overall job satisfaction, and volitional absence. On the other hand, few authors have viewed this construct as a mediator such as Sulu, Cylan \& Kaynak (2010) has viewed work alienation as a mediator between organizational injustice and organizational commitment. However, we have taken special care to exclude all such studies while reviewing the literature as the focus is observing work alienation as an outcome rather than as a predictor or mediator to some other organizational outcomes.

Moreover, in the review process, we observe few published papers focusing on variables that are correlated with work alienation. Such papers were also excluded from the review process because there was no clear direction as to whether work alienation is taken as a predictor or a consequence. Thus, only the clearly stated independent variables impacting work alienation directly or indirectly has been under the review process. (See Table 2)

\subsection{Findings from the Studies under Review}

In order to identify the statistically proven antecedents of work alienation, we review the literature as presented in TABLE II (in appendix). As the table suggests, many researchers have attempted to statistically link alienation to its various antecedents. The research has been done in various organizational settings and in different countries.

The work has been done since 1985 when Lang (1985) using multiple moderated regression analysis suggested that lack of personal and work fulfillment are effective predictors of alienation. While identifying the moderators to this relationship, he claimed that background factors were not the true moderators. However, it was statistically observed by him that às compared to other individuals, those that belong to privileged families and studied in top elite colleges showed stronger impact on the suggested relationship.

Michaels, Cron, Dubinsky \& Joachimsthaler (1988) statistically identified role ambiguity and role conflict to be important predictors to alienation. 
Ramaswami, Agarwal \& Bhargava (1993) investigated the domains of supervisory, task and organizational structure to identify new drivers to work alienation. They tested total 9 variables as an antecedent to work alienation. Out of these 9 variables, 2 variables (Initiation of structure and consideration) belonged to supervisory domain, 4 variables (variety, autonomy, identity, feedback) belonged to task domain and remaining 3 variables (Participation, formalization \{Job codification \& Rule observation $\}$ belonged to organizational structure domain. The indirect impacts of these factors were also checked through their impact on role stress \{role ambiguity and role conflict $\}$ and organizational commitment. They statistically comprehended variety, participation and rule observation to be strong predictors of alienation. In the same year, Zeffane (1993) identified through F-test and multiple regression that at an individual level, the participation as well as uncertainty and organizational change have significant impact on an individual's feelings of alienation.

Sarros, Tanewski, Winter, Santora \& Densten (2002) used Structured Equation Modeling in an attempt to predict work alienation through the drivers of behavior of leader (transactional and transformational style) and organizational structure (formalization and centralization). Through the results of statistical analysis, they observed that organizational structure does not play a significant role in predicting alienation. However, transactional leadership style seemed to cause high alienation as compared to transformational style, where level of alienation was found low comparatively.

Banai, Reisel \& Probst (2002) identified that individual locus of control, job characteristics and leadership did explain work alienation. The sample was taken initially from Hungary but, right after two years Banai \& Reisel (2007) took a larger sample size from 6 nations and again checked leadership and job characteristics where they found similar results as generalizable from their previous study in 2002. They found both supportive leadership and job characteristics to be predictors of alienation. Apart from hierarchical regression that they used in both studies, an additional ANOVA test was run for the latter so that probable sample differences among countries can be checked.

Nair \& Vohra (2010) used Structured Equation Modeling to check various antecedents that they broadly classified under the domains of structure, task nature, work relationships and perceptions of justice. Centralization, formalization were checked under the domain of structure; Extent of autonomy, variety, challenge and creativity, meaningfulness, self expressiveness was analyzed under the domain of nature of task and procedural, distributive was checked under the domain of justice perceptions. They statistically comprehended that among all the drivers tested, the strongest one was lack of meaningful work, followed by inability to express one self and low quality of work relationships.

In the same year, Howard \& Cordes (2010) again checked perceived procedural and distributive justice with various outcomes including work alienation. However emotional exhaustion was also analyzed as a mediator between the relationships. They concluded that both forms of justice does influence work alienation directly and indirectly through emotional pathways.

Isralowitz, Reznik \& Belhassen (2012) used ANOVA test to reveal that work alienation as a dependent variable is related to country of origin, substance (smoking, drinking 
etc.) and cannabis use among males of Isreal. In the same year, Ilan (2012) contributed the literature by analyzing the impact of income on alienation. Value of money was also checked as a moderating variable between the relationship of income and alienation. They concluded that composition of pay has an independent impact on alienation. Moreover, if an individual has more control over amount of income and if there has been a recent increment in income, then that individual is less prone to alienation beyond the effect of the level of income that he/she has.

Yýldýza \& Paylýkay (2014) on a sample of banking employees checked the impact of different dimensions of organizational cynicism on different dimensions of alienation. They concluded the organizational cynicism is related to alienation.

Shantz, Alfes \& Truss (2014) collectively checked the impact of meaningfulness, lack of voice and person-job fit on alienation as suggested that all these factors have a substantial combined effect on work alienation that employee faces.

In the same context, Shantz, Alfes, Bailey \& Soane (2015)predicted work alienation through the impact of decision-making autonomy, task variety, task identity, and social support on it. Their results showed that task variety and identity has negative association with work alienation.

\section{CLASSIFICATION OF ANTECEDENTS WITH RESPECT TO FREQUENCY OF OCCURRENCE/INCORPORATION IN MODELS}

Moving our lens towards the in-depth analysis on the number of times an individual antecedent has been statistically worked upon, we see task variety and autonomy as the most popular ones. Task variety has been used in their study by Ramaswami, Agarwal \& Bhargava (1993), Nair \& Vohra (2010) and also very recently by Shantz, Alfes , Bailey \& Soane (2015). Similarly, Task autonomy also seems to receive equal popularity and is used to predict alienation by Ramaswami, Agarwal \& Bhargava (1993), Nair \& Vohra (2010) and is also checked by Shantz, Alfes, Bailey \& Soane (2015) in the context of decision making autonomy. Meaningfulness of work is used as antecedent by Nair \& Vohra (2010) and later also by Shantz, Alfes \& Truss (2014). In the similar way, task identity was statistically checked as an antecedent by Ramaswami, Agarwal \& Bhargava (1993) and later repeated test was done by Shantz, Alfes, Bailey \& Soane (2015). Perceptions of justice's independent impact was checked initially Nair \& Vohra (2010) and in the same year Howard \& Cordes (2010) again checked it but with an inclusion of emotional exhaustion as a mediator.

Lack of self-expressiveness is regarded as a driver by Nair \& Vohra (2010) and also synonymously predicted as lack of voice by Shantz, Alfes \& Truss (2014). Participation was statistically connected to alienation by Ramaswami, Agarwal \& Bhargava (1993) and in the same year by Zeffane (1993) aswell. Leadership was given importance as an antecedent in same year by Sarros, Tanewski, Winter, Santora \& Densten (2002) as well as by Banai, Reisel \& Probst (2002). 
However, organization structure is a factor that though has been tested thrice in studies by Ramaswami, Agarwal \& Bhargava (1993);Sarros, Tanewski, Winter, Santora \& Densten (2002) and Nair \& Vohra (2010).none has claimed it to be a strong predictor. Infact, Ramaswami, Agarwal \& Bhargava (1993) checks the indirect impact on it through role stress and organizational commitment. It is noted here that role stress (ambiguity and conflict) has been initially already considered as an important antecedent by Michaels, Cron, Dubinsky \& Joachimsthaler (1988). The rest of the variables have only once been tested in literature.

\section{Where Do We Go From Here? Conclusion and Future Research Direction}

Since work alienation is recently declared as an understudied construct in management theory (Shantz, Alfes , Bailey \& Soane;2015) and having consistent views with recent scholars Shantz, Alfes \& Truss (2014) stating that in this $21^{\text {st }}$ century, HRM's focal point should be work alienation; we made an attempt to provide a narrative review of statistically tested antecedents or work alienation.

Our review confirms that although researchers have attempted to make contribution to literature by identifying potential antecedents as suggested by relevant theories, very little work has been done that statistically confirmed a variables' impact on alienation. It seems that the work in this area is either still at its infancy or has not received its due importance. This is so because we observed during our review that most of the antecedents were repeatedly checked by authors in different organizational settings and countries. We also observed that most of the authors have used the already tested variables as identified in earlier studies by Ramaswami, Agarwal \& Bhargava (1993) and Nair \& Vohra (2010).

However, in this section, we present research agenda that we believe can be helpful for future researchers in their attempt to provide further insights into the causes of work alienation.

\section{Identify and Test More Potential Drivers}

The review revealed that there are many antecedents that although practically appears to be important for the cause of alienation, but had not receive the due importance. We suggest that the antecedents that has been worked upon only once in literature should be given importance. Moreover, many other variables that has never been tested or being analyzed in research models should be checked as antecedents. This will add value to the existing literature as we observe very few variables that have been statistically proved to be the predictors of alienation.

\section{Address Research Design Issues}

Issues related to the research design of work alienation needs attention. The review reveals that previous studies have not focused on investigating and collecting the data from entire population rather sampling is done. One issue with selection on sample is 
the extent to which the sample is representative of the target population under study. It is seen that the many studies under review lacks in proving that the sample used is the representative sample of the population on which they have conducted research. Thus, it brings question to the validity of results as the outcomes and findings of research may then be less generalizable.

\section{Identify The Direction of Correlational Factors}

In our review process while selecting the research papers for our review, we observe that few studies identified many new factors have correlation with work alienation such as Organizational identification, Protestant work ethic, Leisure ethic, Work self-discipline, Job involvement-role (Efraty \& Wolfe, 1988; Hirschfeld \& Field, 2000). However, although these studies proved that these variables have association with work alienation, we omitted such studies from analysis because they do not provide a clear idea about the causality effect, i.e. which of the factor is predictor and which is the outcome. An attempt to clear this simple ambiguity can also add value in literature by enriching literature with new knowledge. Moreover, longitudinal studies are suggested to provide a more definite conclusion regarding the direction of variables.

\section{Identify Mediation and Moderation Impacts}

Our analysis reveals that very little work has been done on developing a model where factors are taken as a mediator or moderator to the relationship between work alienation with its predictor. Initially, Lang (1985) checked background factors as moderator and later, Ilan (2012) checked value of money as a moderator. Howard \& Cordes (2010) checked emotional exhaustion as mediator. We suggest that a better model can be developed if impact of mediator and moderator can also be analyzed.

One way to do this can be by positioning any of the antecedents of work alienation as a mediator and analyze literature to identify what causes that mediating variable. For instance, recently Yýldýza \& Paylýkay (2014) came up with a new antecedent to alienation that is organizational cynicism. The same relationship can be extended by analyzing the role of organizational cynicism as mediator and working backwards to identify the cause of cynicism. This is an interesting attempt as it will increase knowledge in the body of existing literature by checking whether an already tested antecedent of mediator variable is also an antecedent to work alienation. Since mediation technique as developed by Barron and Kenny (1986) suggests checking a direct impact of antecedent not only on mediator but also on outcome as one of its four suggested steps, this can also help researcher in making comparative analysis.

\section{Analyze the Antecedents to Each Sub-Dimension of Work Alienation As we were faced with the issue of limited number of primary studies on the topic under review, we failed to parse out various sub-dimensions of alienation. In our review process, we observed that the construct has been viewed by few scholars as multidimensional having the dimensions of powerlessness, social isolation, meaninglessness, normlessness and self-estrangement (Seeman, 1959) while few scholars}


argued it to be uni-dimensional (such as Mottaz, 1981; Kanungo, 1982, Hirschfeld, Field, Bedeian, 2000). The future researches may investigate the antecedents to each of the dimension of alienation to provide an in depth analysis of which dimension is impacted by a specific antecedent.

\section{ACKNOWLEDGEMENT}

First of all with a profound gratitude, we are thankful to Almighty Allah forgiving us success, knowledge and understanding without which we would not been capable of completing this research paper.

We are also profoundly grateful to all our family members whose endurance and understanding have played a significant role in our success by sacrificing the important family time and supporting us all over the research work.

We are finally thankful to the editor, reviewers and IBT specially who provided us with the opportunity to publish our research paper in this esteemed journal.

\section{REFERENCES}

Armstrong-Stassen, M. (2006) 'Determinants of how managers cope with organizational downsizing', Applied Psychology: An International Review, 55, pp.1-26.

Aslan, S., \& Eren, S. (2014) 'The effect of cynicism and the organizational cynicism on alienation', Proceedings of the clute institute of international academic conference, Munich, 2014, pp. 617- 625.

Banai, M., \& Reisel, W. (2003) 'A test of control alienation theory among Cuban workers', Management Research, 1, pp.243-252.

Banai, M., \& Reisel, W. D. (2007) 'The influence of supportive leadership and job characteristics on work alienation: A six-country investigation', Journal of World Business, 42(4), pp.463-476.

Banai, M., Reisel, W. D., \& Probst, T. M. (2004) 'A managerial and personal control model: predictions of work alienation and organizational commitment in Hungary', Journal of International Management, 10(3), pp.375-392.

Baron, R.M., \& Kenny, D.A. (1986) 'The Moderator-Mediator Variable Distinction in Social Psychological Research: Conceptual, Strategic, and Statistical Considerations. Journal of Personality and Social Psychology,(51), pp.1173-1182.

Brandes, Pamela M., (1997) 'Organizational Cynicism: Its Nature, Antecedents, and Consequences',University Of Oklahoma, organizational cynicism Dissertation.

Brender-Ilan, Y. A. E. L. (2012) 'How Do Income and Its Components and Perception Relate to Alienation?', Journal of Applied Social Psychology, 42(2), pp.440470.

Çetin, C., Özdemirci, A. \& Kartaltepe, N. (2009) 'Is Alienation Only A Problem for The Blue-Collar Workers? A Research on The Alienation of The White- 
Collar Workers in the Age of Information and in Banking Sector', The Journal of Financial Research and Studies, 1(1).

Ceylan, A., \& Sulu, S. (2010) 'Work alienation as a mediator of the relationship of procedural injustice to job stress', South East European Journal of Economics and Business, 5(2), pp.65-74.

Cheung, Chau-Kiu, (2008) 'Lagged Harm of Work Restructuring and Work Alienation to Work Commitment', International Journal of Employment Studies, Vol.16, No.2, pp.170-207.

Chisholm, R. F., \& Cummings, T. G. (1979) 'Job characteristics, alienation, and work related behavior: A study of professional employees', Journal of Management, 5, pp.57-70.

Efraty, D., \& Wolfe, D. M. (1988) 'The effect of organizational identification on employee affective and performance responses', Journal of Business and Psychology, 3(1), pp.105-112.

Hirschfeld, R. R., \& Feild, H. S. (2000) 'Work centrality and work alienation: Distinct aspects of a general commitment to work', Journal of Organizational Behavior, 21(7), pp.789-800.

Hirschfeld, R. R., Feild, H. S., \& Bedeian, A. G. (2000) 'Work Alienation as an Individual-Difference Construct for Predicting Workplace Adjustment: A Test in Two Samples', Journal of Applied Social Psychology, 30(9), pp.1880-1902. Howard, L. W., \& Cordes, C. L. (2010) 'Flight from unfairness: Effects of perceived injustice on emotional exhaustion and employee withdrawal', Journal of Business and Psychology, 25(3), pp.409-428.

Isralowitz, R., Reznik, A., \& Belhassen, Y. (2012) 'Work Alienation, patterns of substance use and country of origin among male Hospitality Workers in Israel', International Journal of Mental Health and Addiction, 10(6), pp.923-926.

Jesús Suárez-Mendoza, M., \& Zoghbi-Manrique-de-Lara, P. (2008) 'The impact of work alienation on organizational citizenship behavior in the Canary Islands', International Journal of Organizational Analysis, 15(1), pp.56-76.

Kanungo, R.N. (1982) 'Work Alienation, New York: Praeger

Kanungo, R.N. (1983) 'Work alienation: A cultural perspective', International Studies of Management and Organization, 13, pp.119-138.

Lang, D. (1985) 'Preconditions of three types of alienation in young managers and professionals', Journal of Organizational Behavior, 6(3), pp.171-182.

Marx, K. (1844/1963) 'The Economic and Philosophic Manuscripts of 1844, New York: International Publication.

Michaels, R. E., Cron, W. L., Dubinsky, A. J., \& Joachimsthaler, E. A. (1988) 'Influence of formalization on the organizational commitment and work alienation of 
salespeople and industrial buyers', Journal of Marketing Research,25 (4), pp.376-383. Nair, N., \& Vohra, N. (2009) 'Developing a New Measure of Work Alienation,' Journal of Workplace Rights, 14, pp.293-309.

Nair, N., \& Vohra, N. (2010) 'An exploration of factors predicting work alienation of knowledge workers', Management Decision, 48(4), pp.600-615.

Nair, N., \& Vohra, N. (2012) 'The concept of alienation: towards conceptual clarity', International Journal of Organizational Analysis, 20(1), pp.25-50.

Ramaswami, S. N., Agarwal, S., \& Bhargava, M. (1993) 'Work alienation of marketing employees: Influence of task, supervisory and organizational structure factors', Journal of the Academy of Marketing Science, 21(3), pp.179-193.

Sarros, J. C., Tanewski, G. A., Winter, R. P., Santora, J. C., \& Densten, I. L. (2002) 'Work alienation and organizational leadership', British Journal of Management, 13(4), pp.285-304.

Seeman, M. (1959) 'On the meaning of alienation', American sociological review, 24, pp.783-791.

Shantz, A., Alfes, K., \& Truss, C. (2014) 'Alienation from work: Marxist ideologies and twenty-first-century practice', The International Journal of Human Resource Management, 25(18), pp.2529-2550.

Shantz, A., Alfes, K., Bailey, C., \& Soane, E. (2015) 'Drivers and Outcomes of Work Alienation Reviving a Concept', Journal of Management Inquiry

Suarez-Mendoza, M. J., \& Zoghbi-Manrique-de-Lara, P. (2007) 'The impact of work alienation on organizational citizenship behavior in the Canary Islands', International Journal of Organizational Analysis, pp.15, 56-76.

Sulu, S., Ceylan, A., \& Kaynak, R. (2010) 'Work alienation as a mediator of the relationship between organizational injustice and organizational commitment: Implications for healthcare professionals', International Journal of Business and Management, 5(8), p27.

Tolan, B. (1981) 'Depression of the Modern Sorganizational cynicismiety: Anomy and Alienation', Ankara: Academy of Economics and commercial Sciences's Publications.

Yildiz, S., \& Saylikay, M. (2014) 'The effect of organisational cynicism on alienation', organizational cynicism and Behavioral Sciences, 109, pp.622-627.

Zeffane, R. (1993) 'Uncertainty, participation and alienation: Lessons for workplace restructuring', International journal of sociology and social policy, 13(5/6), pp.22-52. 
Table 1

Journals Used For Review

Journal of International Management

Journal of Organizational Behavior

Journal of Applied Social Psychology

Journal of Marketing Research

The Academy of Management Journal

Journal of the Academy of Marketing Science

Journal of Management Inquiry

The International Journal of Human Resource Management

Management Decision

Journal of business and psychology

Journal of World Business

British journal of management

Journal of International Management

Procedia - Social and Behavioral Sciences

International Journal of Sociology and Social Policy

International Journal of Mental Health Addiction

Journal Of Occupational Behavior 
Table 2

Summary Of Articles Selected For Review

\begin{tabular}{|c|c|c|c|c|}
\hline Authors & Design/Sample & $\begin{array}{l}\text { Statistical } \\
\text { Technique used }\end{array}$ & Antecedents & $\begin{array}{l}\text { Moderators/ } \\
\text { Mediators }\end{array}$ \\
\hline $\begin{array}{l}\text { Lang } \\
\text { (1985) }\end{array}$ & $\begin{array}{l}\text { Convenience sampling to } \\
\text { collect data from } 434 \\
\text { college graduates, out of } \\
\text { which } 85 \% \text { consisted of } \\
\text { full time individuals }\end{array}$ & $\begin{array}{l}\text { Multiple } \\
\text { moderated } \\
\text { regression } \\
\text { (stepwise) }\end{array}$ & $\begin{array}{l}\text { Lack of personal and work } \\
\text { fulfillment }\end{array}$ & $\begin{array}{l}\text { Background } \\
\text { factors } \\
\text { (moderator) }\end{array}$ \\
\hline $\begin{array}{l}\text { Michaels, Cron, } \\
\text { Dubinsky \& } \\
\text { Joachimsthaler } \\
\text { (1988) }\end{array}$ & $\begin{array}{l}\text { Sample consisted of } 330 \\
\text { industrial buyer and } 215 \\
\text { salespeople }\end{array}$ & $\begin{array}{l}\text { Zero order } \\
\text { correlation, } \\
\text { Regression }\end{array}$ & Role ambiguity, Role conflict & \\
\hline $\begin{array}{l}\text { Ramaswami, } \\
\text { Agarwal \& } \\
\text { Bhargava } \\
\text { (1993) }\end{array}$ & $\begin{array}{l}\text { Randomly selected } \\
\text { individuals from the } \\
\text { directory of The } \\
\text { American Marketing } \\
\text { Association (AMA) } \\
\text { membership that was } \\
\text { used as a sampling } \\
\text { frame. Final respondents } \\
\text { were } 352\end{array}$ & $\begin{array}{l}\text { Correlation, } \\
\text { Regression }\end{array}$ & $\begin{array}{l}\text { Task (Task variety, Task } \\
\text { autonomy, Task identity, Task } \\
\text { feedback) } \\
\text { Supervisory (Initiation of } \\
\text { structure, Consideration), } \\
\text { Organizational } \\
\text { Structure(Participation, } \\
\text { Formalization -Job } \\
\text { codification \& Rule } \\
\text { observation) }\end{array}$ & \\
\hline $\begin{array}{l}\text { Zeffane } \\
\text { (1993) }\end{array}$ & $\begin{array}{l}1300 \text { employed } \\
\text { individuals selected from } \\
\text { Australian } \\
\text { telecommunication } \\
\text { Industry }\end{array}$ & $\begin{array}{l}\text { Correlation, } \\
\text { Analysis of } \\
\text { variance (F- } \\
\text { Test), Multiple } \\
\text { regression }\end{array}$ & $\begin{array}{l}\text { Organizational change, } \\
\text { Participation and Uncertainty }\end{array}$ & \\
\hline $\begin{array}{l}\text { Sarros, Tanewski, } \\
\text { Winter, Santora } \\
\text { \& Densten } \\
(2002)\end{array}$ & $\begin{array}{l}326 \text { respondents selected } \\
\text { from US eastern } \\
\text { seaboard fire department }\end{array}$ & $\begin{array}{l}\text { Structured } \\
\text { Equation } \\
\text { Modeling }\end{array}$ & $\begin{array}{l}\text { Leader behavior (transactional } \\
\text { and transformational style) } \\
\text { Organizational structure } \\
\text { (centralization and } \\
\text { formalization dimension) }\end{array}$ & \\
\hline $\begin{array}{l}\text { Banai, Reisel \& } \\
\text { Probst } \\
(2004)\end{array}$ & $\begin{array}{l}395 \text { respondents selected } \\
\text { from five companies in } \\
\text { Hungary }\end{array}$ & $\begin{array}{l}\text { Correlation, } \\
\text { Hierarchical } \\
\text { regression } \\
\text { analysis }\end{array}$ & $\begin{array}{l}\text { Leadership, Job } \\
\text { characteristics, and Individual } \\
\text { locus of control }\end{array}$ & \\
\hline $\begin{array}{l}\text { Banai \& Reisel } \\
\text { (2007) }\end{array}$ & $\begin{array}{l}1933 \text { employed clerical } \\
\text { and administrative } \\
\text { individuals from } 6 \\
\text { counties (Germany, } \\
\text { Cuba, Russia , Israel, } \\
\text { Hungary and the U.S.) }\end{array}$ & $\begin{array}{l}\text { Correlation, } \\
\text { ANOVA, } \\
\text { Hierarchical } \\
\text { regression } \\
\text { analysis }\end{array}$ & $\begin{array}{l}\text { Supportive leadership and } \\
\text { Job characteristics (task } \\
\text { identity, task feedback, job } \\
\text { autonomy, task variety task } \\
\text { significance) }\end{array}$ & \\
\hline $\begin{array}{l}\text { Nair \& Vohra, } \\
(2010)\end{array}$ & $\begin{array}{l}1142 \text { respondents from } \\
\text { India's six different } \\
\text { organizations } \\
\text { in the I.T sector }\end{array}$ & $\begin{array}{l}\text { Structured } \\
\text { Equation } \\
\text { Modeling }\end{array}$ & $\begin{array}{l}\text { Structure (centralization, } \\
\text { formalization) } \\
\text { Nature of work/task } \\
\text { (autonomy, variety, challenge } \\
\text { and creativity, } \\
\text { meaningfulness, self } \\
\text { expressiveness) }\end{array}$ & \\
\hline
\end{tabular}




\begin{tabular}{|c|c|c|c|c|}
\hline & & & $\begin{array}{l}\text { Work relationships } \\
\text { Justice perceptions } \\
\text { (procedural, distributive) }\end{array}$ & \\
\hline $\begin{array}{l}\text { Howard \& } \\
\text { Cordes } \\
(2010)\end{array}$ & $\begin{array}{l}437 \text { randomly employed } \\
\text { individuals selected from } \\
\text { diverse occupations and } \\
\text { industries. }\end{array}$ & $\begin{array}{l}\text { Structured } \\
\text { Equation } \\
\text { Modeling }\end{array}$ & $\begin{array}{l}\text { Perceived justice (procedural } \\
\text { and distributive) }\end{array}$ & $\begin{array}{l}\text { Emotional } \\
\text { exhaustion } \\
\text { (mediator) }\end{array}$ \\
\hline $\begin{array}{l}\text { Isralowitz, } \\
\text { Reznik \& } \\
\text { Belhassen } \\
\text { (2012) }\end{array}$ & $\begin{array}{l}\text { A purposive sample to } \\
\text { collect data from a } \\
\text { subgroup of } 229 \text { males } \\
\text { (hospitality workers) } \\
\text { from three hotel chains } \\
\text { in Eilat, a town resort in } \\
\text { Israel. }\end{array}$ & $\begin{array}{l}\text { Chi square, } \\
\text { t-test and } \\
\text { ANOVA }\end{array}$ & $\begin{array}{l}\text { Country of origin, } \\
\text { Substance use(cigarette } \\
\text { smoking, binge drinking ) } \\
\text { Cannabis use }\end{array}$ & \\
\hline $\begin{array}{l}\text { Ilan } \\
(2012)\end{array}$ & $\begin{array}{l}\text { Network sampling } \\
\text { (snowball type) to } \\
\text { collect data from } 311 \\
\text { full-time employees in } \\
\text { the metropolitan } \\
\text { Washington, D.C. area. }\end{array}$ & $\begin{array}{l}\text { Correlation, } \\
\text { Hierarchical } \\
\text { regression }\end{array}$ & $\begin{array}{l}\text { Income } \\
\text { Objective variables: } \\
\text { (level of work-related } \\
\text { Income, level of non-work } \\
\text { related Income, level of } \\
\text { spousal income, control over } \\
\text { amount of income, increase in } \\
\text { income) } \\
\text { Subjective variables: } \\
\text { Pay satisfaction }\end{array}$ & $\begin{array}{l}\text { Value of } \\
\text { money } \\
\text { (moderator) }\end{array}$ \\
\hline $\begin{array}{l}\text { Yıldıza \& } \\
\text { Şaylıkay (2014) }\end{array}$ & $\begin{array}{l}151 \text { bankers employed } \\
\text { Turkey }\end{array}$ & $\begin{array}{l}\text { Correlation, } \\
\text { Regression, } \\
\text { Independent } \\
\text { Sample t test and } \\
\text { ANOVA } \\
\end{array}$ & Cynicism & \\
\hline $\begin{array}{l}\text { Shantz, Alfes \& } \\
\text { Truss } \\
(2014)\end{array}$ & $\begin{array}{l}227 \text { employed } \\
\text { individuals from a } \\
\text { manufacturing } \\
\text { organization in United } \\
\text { Kingdom. }\end{array}$ & $\begin{array}{l}\text { Correlations, } \\
\text { Latent variable } \\
\text { structural } \\
\text { equation } \\
\text { modeling }\end{array}$ & $\begin{array}{l}\text { Lack of voice, } \\
\text { Person-job fit } \\
\text { Meaningfulness }\end{array}$ & \\
\hline $\begin{array}{l}\text { Shantz, Alfes, } \\
\text { Bailey \& Soane } \\
(2015)\end{array}$ & $\begin{array}{l}283 \text { employed } \\
\text { individuals from a } \\
\text { construction and } \\
\text { consultancy organization } \\
\text { in United Kingdom. }\end{array}$ & $\begin{array}{l}\text { Latent variable } \\
\text { structural } \\
\text { equation } \\
\text { modeling }\end{array}$ & $\begin{array}{l}\text { Decision-making autonomy, } \\
\text { Task variety, Task identity, } \\
\text { and Social support. }\end{array}$ & \\
\hline
\end{tabular}

